\title{
Factors Influencing Attitudes of Hong Kong Secondary School Students toward Physical Education 影響香港中學生對體育課態度的因素
}

\author{
Rebecca Hun Ping CHEUNG \\ School of Early Childhood Education, \\ Hong Kong Institute of Education, HONG KONG
}

㖘杏冰

香港敉育學院幼兒敉育學院

\begin{abstract}
The purpose of this study was to examine the potential influential factors of Hong Kong secondary students' attitudes toward physical education. The Physical Education Questionnaire was completed by 1,172 students, selected proportionally from four main geographic districts in Hong Kong. This instrument measures how physical education is perceived concerning the values, the status, the atmosphere, the experiences, the social aspects, the teaching method and the PE teachers. Mean ratings on these aspects from 3.43 to 3.92 on a 5-point scale, indicating that the students generally liked physical education, but they liked some aspects more that others. Employing analysis of variance techniques revealed that school year, gender and perceived skill competence were significant factors influencing students' attitudes toward physical education. These findings have pedagogical implications for the teaching strategies of physical education.
\end{abstract}

\section{摘 要}

本研究旨在探討影響香港中學生對體育課態度的因素。1,172本地中學生參與問卷調查。研究結果顯示香港中學生對體育課的態 度是正面的, 而級別、性別及運動能力是影響中學生對體育課態度的因素。因此, 體育呚師須了解學生的需要, 從而運用適當的敉育 策略去提升學生對體育課的正面態度。

\section{Introduction}

Developing an active life-style is now a central issue of physical education in Hong Kong. The challenge facing physical educators nowadays is to find out how students can be influenced towards establishing regular physical activity as a long-lasting habit. Experiences in physical education in school may affect students and lead to the development of certain attitudes to regular participation in physical activity. The Health Education Authority (1998) in England stated that student's physical activity habits have a major influence on one's intention to exercise in late life. Successful experience in physical education may have a high impact in students' later lives and it may increase the chances of adult participation. In contrast, dislike of physical education may militate against outside and post-school involvement in physical activity by many students (Williams, 1988; 1996). Appropriate research investigating major influences to students' attitudes toward physical education, could help the researchers, curriculum planners and physical education teachers to be aware of students' needs and interests. It could assist the reform of the physical education curriculum and contribute to the development of 
quality physical education programmes that inculcate life-long habits of exercise.

There are many and varied definition of attitude in the literature and no single, universal acceptable definition exists yet. Kifer (1992) suggested the consideration in providing the definition of attitude for a study should rest on its justification. For the purpose of this study, there is no intention to make a distinction between the cognitive, affective and behavioural components for the measures of attitude, thus the definition of attitude adopted is that of Fishbein and Ajzen (1975) which supports the unidimensional construct of attitude. Attitude is defined as an index of the degree of an individual's likes and dislikes of physical education.

Student attitude is the result of complex interaction of numerous factors. This study focuses primarily on the school context, which is considered to be the most important during secondary schooling. Numerous studies in student attitudes toward physical education have been conducted. Research findings showed that several variables within the school context such as the physical education curriculum (Cockburn, 2001; Ennis, 1996; Solmon \& Carter, 1995)., the physical education teachers (Groves \& Laws, 2000; Coelho, 2000; Macfadyen, 1999), the teaching methods (Williams \& Bedward, 1999; Hurst, 1986), personal physical education experiences (Williams \& Bedward, 1999; Carlson, 1995; Portman, 1995), the values of physical education (Coelho, 2000, Laws \& Fisher, 1999; Chung \& Leung, 1998;) and the status of physical education (Hardman \& Marshall, 2000; Tannehill et al, 1994), provided significant contributions to the formation of student attitudes toward physical education. This provides a starting point for constructing an instrument for the present study.

Many factors affect the way students perceive physical education which may influence the student to have positive or negative attitudes toward physical education. The review of literature revealed that student attitude changes as a function of age, and there is a negative correlation between positive student attitudes and age (Treanor et al., 1998). Younger age students tend to like physical education more than older students. Student gender also plays a role in influencing student attitudes toward physical education (Carlson, 1995; Carroll \& Loumidis, 2001; Kirk \& Claxton, 2000; Nilges, 1998). Adolescent girls are less likely than their male counterparts to participate in physical education and physical activity. Some researchers found that skill level was a major influence on attitudes toward physical education, as those with higher skill levels tended to show more positive attitudes than less able students (Carroll
\& Loumidis, 2001; Cockburn, 2001; Portman, 1995). An understanding of how these factors affect student attitudes toward physical education may inform physical educators in Hong Kong and guide them to develop and strengthen students' positive attitudes and to modify unfavourable attitudes.

The purpose of this study therefore is to investigate the relative importance of factors that influence the attitudes of students toward physical education. The study may reveal implications to be considered for the curriculum reform of physical education. Some useful information may be gained by using the results gleaned from this study to develop a school-based physical education curriculum.

\section{Method}

\section{Subjects}

The sample comprised 1,172 students, 596 boys and 576 girls, drawn from 16 secondary schools in Hong Kong. A "stratified sampling design" was used to obtain the sample representing proportionally the four main geographic districts in Hong Kong: Hong Kong Region, Kowloon Region, New Territories East Region and New Territories West Region (November 2000). Three of the schools were girls' schools, three were boys' schools and the remainder were mixed schools. The sample included a reasonable spread of students between junior form (F.1 - F.3) and senior form (F.4 - F.7), 626 junior students and 546 senior students.

\section{Instrument}

The Physical Education Questionnaire was constructed especially for this study. Statements for the questionnaire were collected from a series of semi-structured interviews from groups of eight students at six mixed secondary school and two singlesex secondary schools in Hong Kong. A pilot study was conducted to establish validity and reliability of the Physical Education Questionnaire.

Attitudes toward physical education are measured by the seven five-point Likert attitude scales comprising 50 statements (see Appendix). The seven scales are: the values of PE, the importance of PE in the school, the class atmosphere of $\mathrm{PE}$, the experiences of $\mathrm{PE}$, the social aspects in $\mathrm{PE}$, the teaching method of PE, the PE teacher. Measurement of the hypothesized influential factors was obtained by asking students to give demographic information and rate their level of physical skills in physical education lessons on a five-point scale. 


\section{Data Analysis}

All responses to every question of the questionnaire were analyzed for descriptive statistics to capture an overall picture. A number of factors including school type, gender, school year, the perceived skill competence were analyzed using ANOVA to investigate main effects of the factors on specific aspects of attitudes toward physical education. An alpha level of .05 was used to determine significance.

\section{Results and Discussions}

The results showed that students in Hong Kong secondary schools generally had positive attitudes toward physical education with an overall mean score of 3.71 for the attitude scales. The PE teacher scale received the strongest agreement $(\mathrm{M}=3.92, \mathrm{SD}=0.61)$ and was ranked the highest in this study, followed by $\mathrm{PE}$ values $(\mathrm{M}=3.84, \mathrm{SD}=0.62)$; $\mathrm{PE}$ atmosphere $(\mathrm{M}=3.82, \mathrm{SD}=0.73)$; the importance of $\mathrm{PE}(\mathrm{M}=3.67, \mathrm{SD}=0$. $70)$; the social aspects $(\mathrm{M}=3.65, \mathrm{SD}=0.74)$; the teaching method $(\mathrm{M}=3.61, \mathrm{SD}=0.60)$; and $\mathrm{PE}$ experiences $(\mathrm{M}=3.43, \mathrm{SD}=0.69)$. The findings indicated that, while students generally have positive attitudes toward physical education, there were differences in their attitudes towards various aspects of physical education. The findings revealed that the PE teacher played an important part in physical education lessons, and consequently influenced student attitudes toward physical education. If the PE teacher adopts an appropriate teaching approach and interacts with students positively, positive attitudes toward physical education of students can be developed. The lowest rank of the PE experience scale for all groups indicated students had a less positive view of the experiences gained from physical education. The emphasis of drill and practice activities in PE might be one of the reasons. In Hong Kong, formal teaching approaches in PE lessons are most common. The PE teacher selects the teaching content, organises and demonstrates activities for skill development, and finally provides opportunities for competitions. Students are expected to practise the tasks organised by the teachers with little opportunity for decision making and social interaction. The teacher-centred approach in physical education that tends to 'push' students into activities based on teachers' planning and emphasizes on skill learning, should be carefully handled.

Table 1. Two-way Analysis of Variance of the Seven Scales for School Year and Gender.

\begin{tabular}{lllll}
\hline Scale & Source & SS & df & F \\
\hline The value of PE & School Year & 8.936 & 1 & $24.273^{* *}$ \\
& Gender & 8.572 & 1 & $23.284^{* *}$ \\
& School Year x Gender & 1.32 & 1 & 3.586 \\
\hline The importance of PE & School Year & 4.164 & 1 & $9.034^{* *}$ \\
& Gender & 21.732 & 1 & $47.141^{* *}$ \\
& School Year x Gender & -0.041 & 1 & 0.90 \\
\hline The atmosphere of PE & School Year & 6.759 & 1 & $13.693^{* *}$ \\
& Gender & 34.832 & 1 & $70.572^{* *}$ \\
& School Year x Gender & -0.004 & 1 & 0.009 \\
\hline The experiences of PE & School Year & 7.094 & 1 & $15.850^{* *}$ \\
& Gender & 27.101 & 1 & $60.549^{* *}$ \\
& School Year x Gender & 0.356 & 1 & 0.795 \\
\hline The social aspects of PE & School Year & 6.753 & 1 & $12.421^{* *}$ \\
& Gender & 5.418 & 1 & $9.966^{* *}$ \\
& School Year x Gender & 0.378 & 1 & 0.695 \\
\hline The teaching method of PE & School Year & 0.327 & 1 & 0.919 \\
& Gender & 0.262 & 1 & 0.738 \\
& School Year x Gender & -0.014 & 1 & 0.041 \\
The PE teacher & School Year & 1.486 & 1 & $4.027^{*}$ \\
& Gender & 1.246 & 1 & 3.376 \\
& School Year x Gender & 0.824 & 1 & 2.232 \\
\hline$* 0 \times 05$ & & &
\end{tabular}


The results indicated that all seven scales except the teaching method, give a significant main effect $(\mathrm{p}<.05)$ of school year, with mean scores decreasing significantly with students in the senior forms. It is suggested that school year is an important factor in determining some of the differences in student attitudes toward physical education. An explanation for the decline in interests of physical education from junior to seniors in Hong Kong might lie in the examination-oriented educational system and the low status of physical education in the school curriculum (Cruz,1998; Hardman \& Marshall, 2000). As physical education is not an examination subject in most of the secondary schools, physical education and physical activities usually are undervalued and are conceived as recreational activities rather than part of the educational process. When students move into the senior forms, they begin to think of their future education and recognize which subjects are most important for reaching academic success. Therefore, the senior students demonstrated less positive attitudes toward the PE importance scale and the PE value scale.

Gender is another important factor in determining some of the differences in student attitudes toward physical education. The male students were found to have significantly $(\mathrm{p}<.05)$ more positive attitudes on the scales of PE values, PE atmosphere, the importance of PE, the social aspects, and PE experiences, compared to the females. Even though on the scales of teaching method and PE teacher, there were no significant differences, the males' mean scores indicated a more positive attitude than the females. The differences between male and female students responses could be a reflection of the popular view found in the literature that males were considerably more enthusiastic about physical education than their female counterparts. As suggested by Carlson (1995), aspects of cultural, societal and school contexts influenced females' attitudes toward physical education. The Hong Kong socio-cultural context has different expectations for boys and girls in connection with sports. Participation in sports is expected for boys and there is general acceptance that boys are better at sports than girls. Therefore, sport is associated with popularity by boys to a far greater extent than by girls. In addition, parental influence in sport involvement also has differential impact on boys' and girls' participation in sports, especially in the Chinese culture. Girls are given less support regarding taking part in sports from their parents, than are boys. The influences posed by the mass media are recognised as variables affecting boys' and girls' participation in physical activities within the social context. Media images constantly promote thin and non-athletic bodies as the ideal for adolescent girls. It seems that the socially constructed view of femininity projects a certain stereotype belief to girls and tends to affect the way how they view their bodies. Certain physical activities, with their masculine image, seem in contradiction with femininity, and consequently negatively influence females' attitudes toward physical education. In contrast, many sporting heroes such as the basketballer Michael Jordan and the footballer David Beckham are promoted by the media and provide messages about sporting role models for boys. Both cultural and societal aspects have a powerful influence on the school context. In the school context, the differences in the scale of the PE atmosphere among males and females indicated that male students got more enjoyment and felt more freedom and less pressure in physical education lessons compared with the females. It seems likely that the traditional physical education curriculum in Hong Kong, which is dominated by competitive games, is beneficial to male students. It is suggested therefore that there is a need to provide a less competitive atmosphere for girls during physical education lessons, whereby girls may be encouraged to learn in a less pressured and more positive way. The frequent hot weather in Hong Kong is perhaps the second reason for the less positive attitudes among secondary female students. Female adolescents did not like to get sweaty and smelly. As adolescent girls generally take good care of appearance, insufficient time to change and take a shower after physical education, contributed to their negative attitudes toward physical education. 
Table 2. One-way Analysis of Variance of the Seven Scales for Perceived Skill Competence.

\begin{tabular}{lllll}
\hline Scale & Source & SS & df & F \\
\hline The value of PE & Between Groups & 40.07 & 4 & $32.77^{* *}$ \\
& Within Groups & 396.42 & 1153 & \\
\hline The importance of PE & Between Groups & 85.91 & 4 & $52.69^{* *}$ \\
& Within Groups & 468.76 & 1150 & \\
\hline The atmosphere of PE & Between Groups & 105.58 & 4 & \multirow{2}{*}{$60.48^{* *}$} \\
& Within Groups & 498.37 & 1142 & \\
\hline The experiences of PE & Between Groups & 107.72 & 4 & \multirow{2}{*}{$69.88^{* *}$} \\
& Within Groups & 443.20 & 1150 & \\
\hline The social aspects of PE & Between Groups & 48.38 & 4 & $23.80 * *$ \\
& Within Groups & 589.46 & 1160 & \\
\hline The teaching method of PE & Between Groups & 2.391 & 4 & 1.69 \\
& Within Groups & 407.44 & 1149 & \\
\hline The PE teacher & Between Groups & 29.91 & 4 & $21.54 * *$ \\
& Within Groups & 401.08 & 1155 & \\
\hline
\end{tabular}

$* p<0.05 \quad * * p<0.01$

Students' self-perception of skill competence in physical education, in relation to specific aspects of physical education under investigation, was an effective factor in explaining some of the differences in students' attitudes toward physical education. The findings of this study showed that the five perceived skill competence groups (very good, good, average, weak, very weak) were significantly different $(\mathrm{p}<.05)$ and displayed a positive relationship for student attitudes to the benefits of PE, the importance of PE, PE atmosphere, PE experience, the social aspects of PE and the PE teacher. As students' self-perception of skill competence in physical education became less positive, their attitudes toward these aspects of physical education also became less positive. Students in the "very good' perceived competence group consistently expressed the most positive attitudes, while students in the 'very weak' competence group expressed least positive or indecision attitudes. The results indicated that self-perception of competence affects students' attitudes toward physical education. An explanation for this relationship might lie in the physical education curriculum in secondary schools. The emphasis on traditional team games in the curriculum, reflects the emphasis on competition. The competitive nature of physical education is beneficial to those who are more competent. When students believe that they are good in skill competence and perceive themselves as successful in physical education, then they are motivated to demonstrate their competence in the activity and to become even more competent. Thus, they are eager to take part in physical education and also enhance their perceived competence. In contrast, low levels of competence often negatively affect students' attitudes due to the repeated unsuccessful experiences. Repeated unsuccessful and negative experiences may make low-skilled students question their ability and give up trying. If this is the case, the experiences that students gain in their physical education lessons will have a great impact on the way they regard their skill competence, thus influencing their attitudes toward physical education. It is suggested that a less competitive atmosphere may be helpful in physical education. Students should be taught not only to develop their skill competencies in physical activities, but also should be given opportunities to achieve improvement, without embarrassment, so that the emphasis of physical education is on process of learning rather than success-failure judgments, skill mastery rather than comparative performance. A mean score of 2.89 in perceived skill competence showed that students in Hong Kong secondary schools perceived themselves only to have average to weak competence in physical education. Although these self-perceptions of competence may not be accurate, the possession of a high level of perceived self-competence may have a positive effect on attitudes toward physical education. Previous research (Lee et al., 1999) suggested physical education teachers could be an influential source of information that students use to make interpretation about their skill competence, especially for the younger students. Physical education teachers can play a pivotal role in helping students to feel more competent 
by evaluating them on effort and improvement rather than outstanding performance. Teachers can help to creating an environment in which all students can be successful, giving challenging but attainable tasks, and providing task related feedback. Male students (a mean score of 3.05) in this study exhibited significantly higher level of perceived skill competence than females (a mean score of 2.74). The male-female differentials in perceived skill competence reinforced the gender differences of attitudes toward physical education.

\section{Conclusion}

Physical education is undergoing change in Education Reform. The introduction of school-based physical education curriculum by the CDC (Curriculum Development Council, 2000) encourages schools to consider students' interests when designing the curriculum and teaching approaches. There is evidence that junior and senior, male and female students have different interests in physical education. It is hoped that the findings of this study may stimulate physical education teachers in Hong Kong to listen to their students and try to understand how the students perceive physical education in order to improve the alignment of teacher views with student interests. Listening to students' voice may provide information that is useful in the reform of the curriculum and instructional practices. The findings of this study reveal that self-perception of skill competence is a major factor influencing attitudes toward physical education. The outcomes of the traditional sport-based curriculum that emphasize skill learning and competitions are problematic and questionable if physical education is striving to foster positive attitudes. A physical education programme that leans heavily on skill learning and physical performance has been criticized by many researchers (e.g. Williams et al., 2000) because many students not only achieve little success in the learning process but also believe they do not have the ability. Students' perceptions of their level of competence affect their motivation and achievement, which in turn, affects attitude and behaviour in physical education. Success is an important element in physical education. As mentioned in the curriculum consultation document of physical education (Curriculum Development Council, 2000), opportunities should be provided for students to enjoy success in physical education, which should be based on many factors rather than solely on physical performance. Therefore, teachers who desire to inculcate positive attitudes amongst students in physical education should move away from the traditional competitive games dominated curriculum in which they feel confident and safe. Teachers need to rethink the skill-based teaching approach, in which makes it easy to quantify students' performance.
Other teaching approaches such as teaching games for understanding (Thorpe, 1992) can be considered to overcome the single measure of success being technical proficiency.

\section{References}

Carlson, T.B. (1995). We hate gym: Student alienation from physical education [Monograph]. Journal of Teaching in Physical Education. 14, 467-477.

Carroll, B., \& Loumidis, J. (2001). Childre's perceived competence and enjoyment in physical education and physical activity outside school. European Physical Education Review, 7 (1), 24-43.

Chung, P., \& Leung, M. (1998). Attitudes toward physical activity among primary school children in Hong Kong and Taiwan. Journal of Health, Physical Education, Recreation, Sport and Dance, 34, 32-37.

Coelho, J.D. (2000). Student perception of physical education in a Mandatory College Program. Journal of Teaching in Physical Education, 19, 222-245.

Cockburn, C. (2001). Year 9 girls and physical education: A survey of pupil perception, The Bulletin of Physical Education, 37 (1), 5-24.

Cruz, A. (1998). Senior female secondary school students' attitude towards physical education in Hong Kong. Journal of Physical Education and Recreation (Hong Kong), 4 (1), 8-16

Curriculum Development Council. (2000). Learning to learn: Key learning area - Physical education (Consultation Document). Hong Kong: Government Printer.

Education Department. (2000). School Lists (By District). Retrieved November, 2000, from Education Department Website: http://www.ed.gov.hk/ednewhp/school-all14.html

Ennis, C.D. (1996). Students' experiences in sport-based physical education: [[More than]] apologies are necessary, Quest, 48, 453-456.

Fishbein, M., \& Ajzen, I. (1975). Belief, attitude, intention, and behavior. Reading, Mass.: Addison-Wesley. 
Groves, S., \& Laws, C. (2000). Childre's experience of physical education, European Journal of Physical Education, 5 (3), 19-27.

Hardman, K., \& Marshall, J. (2000). The state and status of physical education in schools in international context, European Physical Education Review, 6 (3), 203-229.

Health Education Authority. (1998). Young and active policy framework for young people. Health Education Authority.

Hurst, V.E. (1986). Student attitudes towards organizational aspects of secondary school physical education programs. Microfilm Dissertation, National Library of Canada.

Kifer, E. (1992). Attitude measurement. In M.C. Alkin., M. Linden., J. Noel., \& K. Ray (Eds.) Encyclopedia of Educational Research (6 ${ }^{\text {th }}$ ed., pp. 107-114). NY: Macmillan Publishing Company.

Kirk, D., \& Claxton, C. (2000). Promoting girl's participation in physical education and sport: The girls in sport partnership project, The British Journal of Teaching Physical Education, 31 (1), 27-29.

Law, C., \& Fisher, R. (1999). Pupils' interpretation of physical education, In C.A. Hardy and M. Mawer (eds), Learning and Teaching in Physical Education (pp.23-37), London: Routledge.

Lee, A. M., Fredenburg, K., Belcher, D., \& Cleveland, N. (1999). Gender differences in children's conceptions of competence and motivation in physical education, Sport, Education and Society, 4 (2), 161-174.

Macfadyen, T. (1999). An analysis of the influence of secondary school physical education on young people's attitudes towards physical activity. The Bulletin of Physical Education, 35 (3), 157-171.

Portman, P. A. (1995). Who is having fun in physical educaion classes? Experiences of six-grade students in elementary and middle schools [Monograph]. Journal of Teaching in Physical Education, 14, 445-453.
Solmon, M.A., \& Carter, J.A. (1995). Kindergarten and firstgrade students' perceptions of physical education in one teacher's classes. Elementary School Journal, 95, 355365 .

Tannehill, D., Romar, J., \& O'Sullivan, M. (1994). Attitudes toward physical education: Their impact on how physical education teachers make sense of their work. Journal of Teaching in Physical Education, 13 (4), 406-420.

Thorpe, R.D. (1992). New directions in game teaching, Volume 2, In N. Armstrong (Eds.), New Directions in Physical Education (pp.79-100). Leeds: Human Kinetic.

Treanor, L., Graber, K., Housner, L., \& Wiegand, R. (1998). Middle school students' perceptions of coeducational and same-sex physical education classes. Journal of Teaching in Physical Education, 18, 43-56.

Williams, A. (1988). Physical activity patterns among adolescents: Some curriculum implications. Physical Education Review; 11, 22-39.

Williams, A. (1996). Problematising physical education practice: Pupil experience as a focus for reflection. European Journal of Physical Education, 1 (1), 19-35.

Williams, A., \& Bedward, J. (1999). A more inclusive curriculum framework (QCA 1999) - Making physical education relevant to adolescent girls. The British Journal of Physical Education, 30 (3), 6-10.

Williams, A., Bedward, J., \& Woodhouse, J. (2000). An inclusive National Curriculum? The experience of adolescent girls. European Journal of Physical Education, 5, 4-18. 


\section{Appendix. Statements of the Seven Scales:}

\section{體育的價值：}

1. 體育課可增進健康。

2. 體育課可提高體能。

3. 體育課可鍛練㥀心和毅力。

4. 體育課可發展學生的運動潛能。

5. 體育課使我認識體育活動的技能。

6. 體育課幫助我懂得如何欣賞運動比賽。

7. 體育課可增進我的運動技能。

\section{體育在學校的重要性 :}

1. 我覺得體育課在學校的課程中是必須的。

2. 我覺得在學校的課程中, 體育課無關重要。

3. 基本的運動技能是每個人都要懂的, 所以體育課是重要的 $\circ$

4. 體育課不應該是必修的, 因為它的重要性較其他科目低。

5. 我覺得體育課是學校 唯一可將學到的知識實踐的一個科 目, 所以是必須的。

6. 體育課能讓我有活動的機會, 所以必須納入學校的課程 內。

7. 對平時少做運動的人, 體育課是必須的。

8. 體育課與其他科目一樣重要。

\section{體育課的䛪堂氯氛：}

1. 體育課可以調劑一下課堂的壓力。

2. 我覺得體育課較其他課堂自由, 所以我喜歡。

3. 我覺得體育課很沉悶。

4. 我喜歡體育課, 因為不必坐在課室内聽書。

5. 我喜歡體育課, 因為令我很開心。

6. 我喜歡體育課, 因為較其他課堂輕鬆。

7. 體育課應給予足夠的時間讓學生進行的比賽。

8. 我覺得一星期祇有一次體育課是不夠的。

\section{體育課的經驗：}

1. 我不喜歡體育課, 因為要更衣上課, 很麻煩。

2. 體育課後, 我覺得精神特別好。

3. 與朋友一起參予體育活動, 我覺得很開心。

4. 我喜歡參予體育課, 因為有挑戰性。

5. 我不喜歡體育課, 因為會令我覺得很疲倦。

6. 若體育課進行我不擅長的體育活動, 我便不喜歡上體育 課。

7. 我喜歡體育課, 因為從練習中得到進步, 使我獲得滿足 感。
8. 若體育課進行我不喜歡的體育活動, 我寧願不上體育 課。

9. 我喜歡體育課, 因為它比其他課堂更能訓練群體精神。

10. 我喜歡體育課, 因為它能提供更多群體活動的機會, 這 是其他科目不能做到的。

11. 體育課訓練體能的方法很好。

\section{體育諃的社交層面：}

1. 和同學一起進行體育活動, 可使我們有更多的溝通, 相 處更融洽。

2. 體育課使我有機會認識新朋友。

3. 體育課可以培養群體精神。

4. 體育課讓我學會如何與別人合作。

\section{體育的数學方法：}

1. 體育課訓練體能的方法不應每次均一模一樣。

2. 在雨天體育課堂觀看錄影帶, 我覺得很沉悶。

3. 我覺得體育課的熱身活動不應千篇一律。

4. 我覺得體育課的熱身時間不必太長。

5. 上體育課時, 不應不斷重覆練習某動作。

6. 我覺得體育課不應太著重呚授單一的技巧。

\section{體育老婴：}

1. 於體育課堂, 老師的教導是很重要的。

2. 有體育老師的敎導, 我會覺得更安全。

3. 有體育老師的敉導, 我會學得更多。

4. 我覺得體育老師的運動知識必須全面。

5. 有體育老師的鼓勵, 我日後會更積極的參予體育活動。

6. 體育老師應提供資料, 使學生可於課餘發展有興趣的體 育活動。 